\title{
Biogeochemical Assessment of a Zn-Contaminated Site Using Scots Pine (Pinus sylvestris L.) Needles as Phytoindicators
}

\author{
Jean Diatta ${ }^{1}$, Jerzy Nawracała ${ }^{2}$, Agnieszka Andrzejewska ${ }^{1}$, Ewa Chudzińska ${ }^{3}$, \\ Agata Duczmal-Czernikiewicz ${ }^{4}$
}
${ }^{1}$ Poznań University of Life Sciences, Department of Agricultural Chemistry and Environmental Biogeochemistry, Wojska Polskiego 71F, 60-625, Poznań, Poland
${ }^{2}$ Poznań University of Life Sciences, Department of Genetics and Plant Breeding,
Dojazd 11, 60-632, Poznań, Poland
${ }^{3}$ Adam Mickiewicz University, Institute of Experimental Biology, Department of Genetics,
Umultowska 89, 61-614 Poznań, Poland
${ }^{4}$ Adam Mickiewicz University, Institute of Geology and Department of Mineralogy and Petrology, Maków Polnych 16, 61-606 Poznań, Poland

Received: 18 February 2016

Accepted: 27 May 2016

\begin{abstract}
The aim of our study was to evaluate the mobility of $\mathrm{Zn}$ in soils subjected to the activity of a zinc smelter and to assess the contamination of 1- and 2-year-old needles of Scots pine species sensitive to and tolerant of heavy metal contamination, particularly zinc. The trees were selected on the basis of their morphology, i.e., tolerant ones exhibited quite normal growth shape, but sensitive ones were more or less dwarves. Mineralogical composition revealed the prevalence of kaolinite in all soils except for two samples, where smectite dominated. Zinc contamination exceeded 30 times the geochemical background, and the reactive $\mathrm{Zn}$ forms represented $34.6 \%$ of total $\mathrm{Zn}$ content $\left(\mathrm{Zn}_{\text {Total }}\right)$. Proton generation capacity $(\alpha)$ indices calculated for the bioavailable $\mathrm{Zn}$ fraction $\left(\mathrm{Zn}_{\mathrm{Bio}}\right)$ were $59 \%$ higher compared to the reactive $\mathrm{Zn}$ pool $\left(\mathrm{Zn}_{\text {Reac }}\right)$. Two-year-old tolerant (T) pine needles accumulated 21.9, 38.2, and 13.6\% more $\mathrm{Zn}, \mathrm{Fe}$, and $\mathrm{Mg}$, respectively, as compared to 1-year-old ones. For sensitive (S) needles, the range followed: 12.4, 48.8, and $7.3 \%$, respectively. Iron was considered a "strategic survival element" for both pines growing under high zinc pollution.

The transfer of $\mathrm{Zn}$ ions from the soil environment to plants still remains the basic source of maintaining its high concentrations in the needles, since air emissions ceased in 1996. The amounts of $\mathrm{Zn}$ accumulated by Scots pine at crucial years of metallurgical emissions may be considered as an additional time-constant source due to the evergreen vegetative lifecycle.
\end{abstract}

Keywords: soil, $\mathrm{Zn}$, contamination, mineralogy, Scots pine, $\mathrm{Mg}$, Fe, needles

*e-mail: Jeandiatta63@yahoo.com 


\section{Introduction}

The natural zinc $(\mathrm{Zn})$ concentration in the soil is generally not toxic for the flora and fauna. Several physical as well as chemical soil processes interact to maintain $\mathrm{Zn}$ in the soil solution at levels not impairing any biological functions [1]. Unfortunately, the anthropogenic pressure and the resulting environmental pollution via industrial emissions of chemicals, including $\mathrm{Zn}$, are of great concern [2-3]. These actions tend to drastically raise the concentrations of $\mathrm{Zn}$ beyond safe thresholds in the soil environment, leading to the worsening of biological activities and simultaneously increasing $\mathrm{Zn}$ phytoaccumulation [4]. Zinc occur in soils under different compounds sorbed by mineral and organic colloids or as ions in the soil solution [5]. Its mobility in soil compartments and uptake by plants is strongly regulated and controlled by soil $\mathrm{pH}$ [6-7]. Several functions and physiological processes such as growth hormones and protein and carbohydrate synthesis are mediated by $\mathrm{Zn}$ in plants. High concentrations may induce negative plant responses, resulting in chlorosis and necrosis [8].

In general, organisms used for evaluating the state of the natural environment are defined as indicators (bioindicators), of which phytoindicators represent one of the core groups [9]. According to European Parliament data [10], more than $42 \%$ of EU land area is covered with forest and other wooded land. The main component of coniferous forests growing in Europe is Pinus sylvestris L., a species commonly used in passive biomonitoring of environmental pollution [11-12]. The advantage of conifers as evergreen species is that, in contrast to deciduous trees, they can accumulate atmospheric pollutants over several years. The intensity of these stressors are reflected by the chemical composition of the needles [13-15].

The aims of the current work were to investigate $\mathrm{Zn}$ content and its potential mobility in soils contaminated by a $\mathrm{Zn}$ smelter. In addition, the study deals with the assessment of $\mathrm{Zn}$ as well as $\mathrm{Mg}$ and $\mathrm{Fe}$ concentrations in one- and two-year-old Scots pine (Pinus sylvestris) needles of sensitive $(\mathrm{S})$ and tolerant $(\mathrm{T})$ species for evaluating the direct impact of $\mathrm{Zn}$ pollution on $\mathrm{Mg}$ and Fe phytoaccumulation. The link between $\mathrm{Zn}$ in soils and in needles with its possible phytotoxicity was also investigated.

\section{Materials and Methods}

\section{Sampling Zone Characteristics}

The study area is the impact zone of the $\mathrm{Zn}$ smelter located at Miasteczko Śląkie (N 51 $41^{\prime} 03^{\prime \prime}$ and E 15'57'12", Poland). The investigated zone is dominated by northern and southwestern $(21.4 \%)$ plus western $(18.7 \%)$ winds. This creates much more pollution concerns for areas located to the east and southeast toward the smelter emitters. The course of biannual emissions of dusts and metallic Zn (Fig. 1) was irregular, but there was

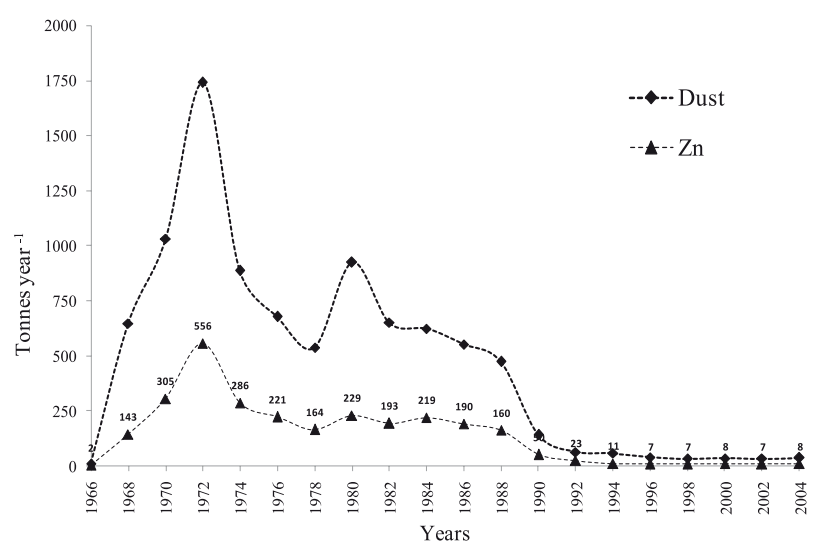

Fig. 1. Course of biannual emission of dusts and metallic $\mathrm{Zn}$ for the time-range 1966-2004 [12].

a decreasing trend from 1966 to 2004 [12]. For the timerange 1996-2004, emissions stabilized at mean levels of 34 and 7 tons per year for dusts and $\mathrm{Zn}$, respectively.

Forty soil samples were collected on June 2012 at a depth $0-20 \mathrm{~cm}$. Sampling proceeded along a transect, mostly in an easterly direction toward the smelter (like the number five on a dice). Next, eight composite soils were made (from thoroughly mixing five single samples), representing eight localities as reported in Table 1.

\section{Soil Chemical Analyses}

Prior to physical and chemical analyses, soil samples have been dried at ambient room temperature and passed through a $2 \mathrm{~mm}$ sieve mesh. Soil particles were determined using the methods described by soil survey staff [16], w here three fractions (sand, silt, clay) were separated. Soil $\mathrm{pH}_{\mathrm{H} 2 \mathrm{O}}$ as well as electrical conductivity (EC) were measured in an aqueous solution at a soil/distilled water ratio as $1: 2.5$, [17]. Moreover, $\mathrm{pH}$ was additionally

Table 1. Distribution of respective soil sampling sites.

\begin{tabular}{|c|c|}
\hline $\begin{array}{c}\text { Soil } \\
\text { No }\end{array}$ & Location \\
\hline 1,2 & $\begin{array}{c}\text { Experimental site with young pines, distant at 500 } \\
\text { m from the emitter, ESE direction }\end{array}$ \\
\hline 3 & $\begin{array}{c}\text { Cynkowa street, distant at } 100 \mathrm{~m} \text { from the emitter, E } \\
\text { direction (Miasteczko Slaskie) }\end{array}$ \\
\hline 4 & $\begin{array}{c}\text { Dworcowa street, distant at 500 m from the emitter, } \\
\text { SE direction (Miasteczko Slaskie) }\end{array}$ \\
\hline 5 & $\begin{array}{c}\text { Brynicka street, distant at 500 m from the emitter, } \\
\text { SE direction (Zyglin) }\end{array}$ \\
\hline 6 & $\begin{array}{c}\text { St Mark street, distant at 1500 m from the emitter, } \\
\text { SE direction (Zyglin) }\end{array}$ \\
\hline 8 & $\begin{array}{c}\text { Zyglinska street, distant at 4500 m from the emitter, } \\
\text { E direction (Brynica) }\end{array}$ \\
\hline
\end{tabular}


determined in a $0.01 \mathrm{~mol} \mathrm{CaCl}_{2} \mathrm{dm}^{3}$ solution at a ratio of 1:5 and designated as $\mathrm{pH}_{\mathrm{CaCl} 2}$ [18]. The content of oxidizable organic carbon was assayed according to Wang et al. [19], whereas the effective cation exchange capacity $\left(\mathrm{CEC}_{\text {ef. }}\right)$ was evaluated first by extracting $\mathrm{Ca}^{2+}, \mathrm{Mg}^{2+}, \mathrm{K}^{+}$, and $\mathrm{Na}^{+}$using $1 \mathrm{~mol} \mathrm{CH}_{3} \mathrm{COONH}_{4} \mathrm{dm}^{-3}(\mathrm{pH} 7)$, and next summing these ions along with hydrolytic acidity (where necessary) [20-21].

Total $\mathrm{Zn}$ content was determined by hot extracting soil samples with aqua regia: ( $\mathrm{HCl}_{\text {conc. }}: \mathrm{HNO}_{3 \text { conc. }} 1: 3$ ratio), [22]. Next the concentrations of bioavailable $\left(\mathrm{Zn}_{\mathrm{Bio}}\right)$ as well as reactive $\left(Z_{\text {neac }}\right)$ zinc forms were assessed by the chemical tests $0.10 \mathrm{~mol} \mathrm{NaNO}_{3} \mathrm{dm}^{-3}$ [23] and $0.11 \mathrm{~mol}$ $\mathrm{CH}_{3} \mathrm{COOH} \mathrm{dm}{ }^{-3}$ (first fraction), according to the BCR method [24], respectively. All elements (Ca, Mg, K, Na, and $\mathrm{Zn}$ ) extracted by the reported tests were determined with the absorption spectrometry method (AAS) by using a Varian 250 Spectra Plus (Australia).

Bulk soil mineralogy of selected soil samples was assessed by random powder $\mathrm{x}$-ray diffraction (Thermo ARL SCINTAG X'TRA X-ray diffractometer, USA, with $\mathrm{Cu}$ $\mathrm{K} \alpha$ irradiation). Clay mineral fraction $<2 \mu$ m was obtained using the sedimentation method. The samples were centrifuged twice for 15 min using a Sigma 4-15 centrifuge. The clay suspensions were pipetted onto a glass slide and left to dry at an ambient temperature. Clay mineral species were determined based on the oriented air-dried (untreated) samples, and ethylene glycol-solvated and heated $\left(550^{\circ} \mathrm{C}\right)$ samples according to the methods described by Środon [25]. Because the clay mineral peaks were well resolved, no treatment was necessary for the removal of carbonates or organic matter. Measurements were done at $40 \mathrm{kV}$ and $40 \mathrm{~mA}$ and scan rates from 3 to $30^{\circ} 2 \theta$ (or from 2 to $30^{\circ} 2 \theta$ ) at $0.02^{\circ} 2 \theta \mathrm{min}^{-1}$ step size. Phase identification and peak area determinations were done using Win XRD software. XRD analyses were performed at the Institute of Geology, Adam Mickiewicz University, Poznan, Poland.

\section{Evaluation of Zn Geochemical Processes}

The reaction of $\mathrm{Zn}$ with soil colloids was evaluated by applying the index expressing the Proton Generation Capacity (PGC), $(\alpha)$ as described by the relations (Rel. $1,2,3)[26]$. It is assumed that deprotonation of various functional groups takes place when $\mathrm{Zn}$ sorption and retention proceed. This leads to the release of $\mathrm{H}^{+}$, which consequently tends to enhance $\mathrm{Zn}$ mobility and activity in the soil solution, as reported below:

$$
\begin{aligned}
(\equiv-\mathrm{OH})_{n}+\mathrm{M}^{z+} & \rightarrow(\equiv-\mathrm{O})_{n} \mathrm{M}(z-n)^{+}+\underset{\mathrm{n} \mathrm{H}^{+}}{(\text {Rel. }} \\
\mathrm{Me}^{2+}{ }_{(a q)}+n \mathrm{H}_{2} \mathrm{O} & \rightarrow \mathrm{Me}(\mathrm{OH})_{n}^{2-n}+\mathrm{n} \mathrm{H}^{+} \\
S-H_{\alpha}+M^{2+} & \rightarrow S-M+\alpha H^{+}
\end{aligned}
$$

...where $\mathrm{M}^{2+}$ and $\mathrm{Me}^{2+}$ express metallic ions (i.e., $\mathrm{Zn}^{2+}$ ), $S-H_{\alpha}$ is active soil sorptive sites, $\boldsymbol{\alpha}$ is proton index expressing the number of $\mathrm{H}^{+}$moles generated when $\mathrm{Zn}$ reacts with soil, $M^{2+}$ is soluble/active $\mathrm{Zn}$ ions, and $S-M$ is sorbed $\mathrm{Zn}$ ions.

$$
\begin{gathered}
K=\frac{(S-M) *\left(H^{+}\right)^{\alpha}}{\left(M^{2+}\right) *\left(S-H_{\alpha}\right)} \\
\log \left(K_{d}\right)=\alpha p H+\log K *(S-H) \\
\mathrm{K}_{\mathrm{d}}=\frac{\text { Amount of } \mathrm{Zn} \text { sorbed in the soil }\left(\mathrm{mg} \mathrm{kg}^{-1}\right)}{\text { Concentration of } \mathrm{Zn} \text { in the soil solution }\left(\mathrm{mg} \mathrm{dm}^{-3}\right)}
\end{gathered}
$$

...where $K_{d}$ expresses the distribution coefficient $\left(\mathrm{dm}^{3} \mathrm{~kg}^{-1}\right)$.
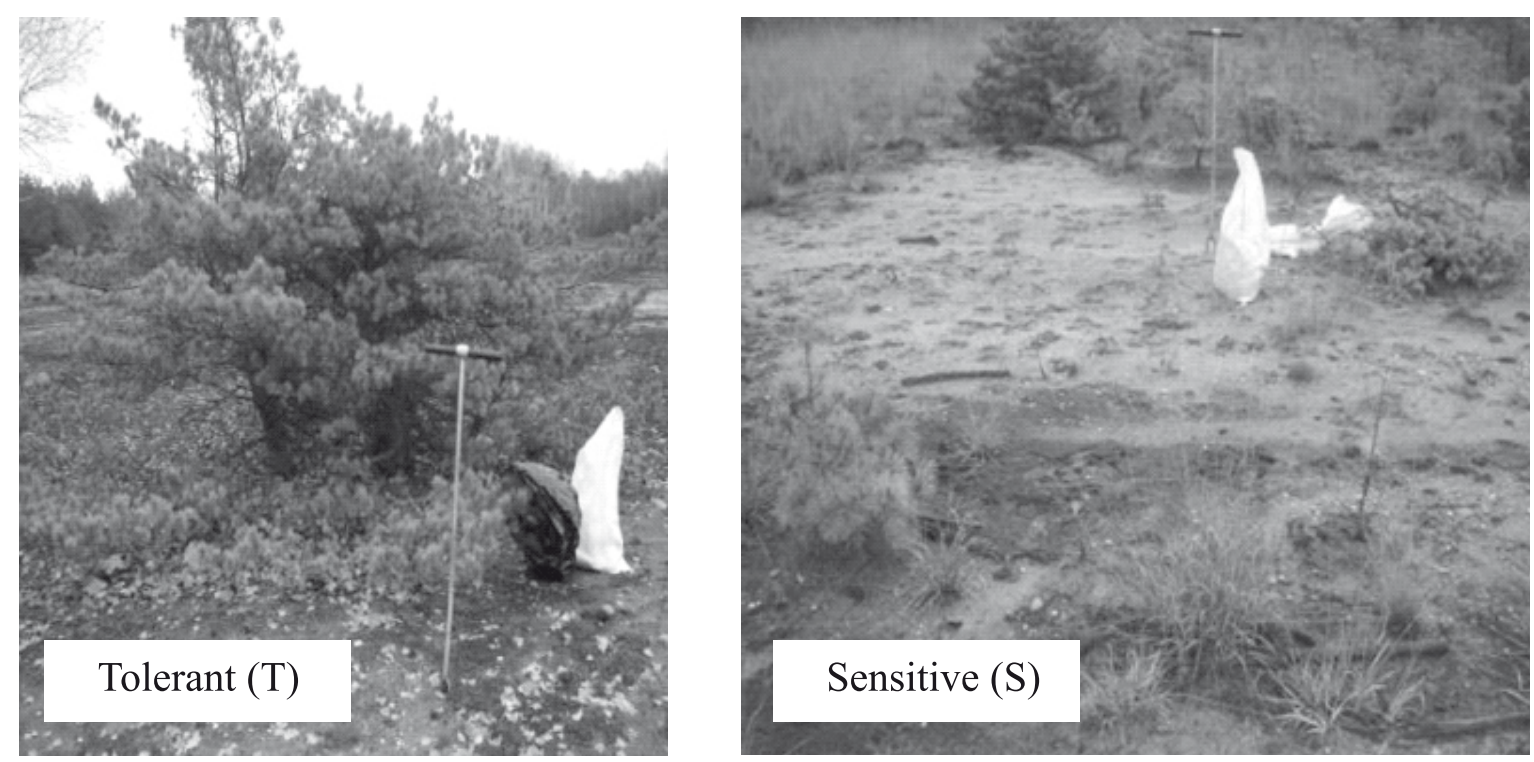

Photo 1: Tolerant (T) and sensitive (S) Scots pine species considered for the study (2012). 
The expression from Eq. 2 outlines the linear form $\mathrm{y}=\mathrm{a} x+\mathrm{b}$, where $\mathrm{y}=\log \mathrm{K}_{\mathrm{d}}, \mathrm{a}=\alpha, x=\mathrm{pH}$, and $\mathrm{b}=\beta$. This is a relationship established for the pairs: distribution coefficient $\left(\mathrm{K}_{\mathrm{d}}\right)$ versus $\mathrm{pH}_{\mathrm{H} 2 \mathrm{O}}$ and/or $\mathrm{pH}_{\mathrm{CaCl} 2}$. The retention capacity $(\mathrm{RC}),(\beta)$, explains how strongly and intensively investigated soils are able to retain/immobilize $\mathrm{Zn}$ ions. The highest the $\beta$ values, the much more $\mathrm{Zn}$ ions are retained by soils (and inversely).

\section{Plant Materials (Pine Needles)}

The plant materials consisted of 1- and 2-year-old needles sampled from two pine species subjected to $\mathrm{Zn}$ smelter activity. These pines exhibited tolerance and sensitivity to heavy metals, but particularly to $\mathrm{Zn}$ - the main polluting metal. The trees for needle sampling were selected on the basis of tress morphology [27], i.e., exhibiting normal growth shape as compared to sensitive ones, which were more or less dwarves (Photo 1). Needles were harvested from the middle third of the crown of randomly selected trees of both species: tolerant ( $\mathrm{T}=24$ trees $)$ and sensitive $(\mathrm{S}=24$ trees $)$.

In total, 40 needles (10 needles per direction, i.e., east, west, north, south), 1- and 2-year-old were sampled from each tolerant and sensitive pine. Dusts and other impurities were washed from the needles using distilled water. Prior to grinding, needles were dried at $60^{\circ} \mathrm{C}$ for three days. Portions $(0.250 \pm 0.001 \mathrm{~g})$ of ground needles were weighed into test tubes and mineralised in concentrated $\mathrm{HNO}_{3}$ (MARS5, CEM Corporation, USA). The digests were filtered and $\mathrm{Zn}, \mathrm{Mg}$, and Fe were determined using AAS (Varian 250 Spectra plus). All analyzed (soils and needles) were run in duplicates. Simplified statistical summary and graphical sets were performed using Excel.

\section{Results and Discussion}

Soils within industrial areas are frequently subjected to contamination by several substances, of which heavy metals are of great concern due to the fact that they are not biodegradable [2]. These characteristics are responsible for their behavior in the biotic as well as abiotic media. In the case of $\mathrm{Zn}$, it should be mentioned that this metal is important for the metabolism of the flora and fauna, but at relatively excessive concentrations both in the soils and plant shoots its effects are considered potentially harmful. The input of metalliferous compounds into soils additionally alters soil chemical properties such as $\mathrm{pH}$ and buffering properties, which in turn regulate and control metal geochemical processes. For such reasons, anthropogenic $\mathrm{Zn}$ occurs much more frequently in mobile and reactive forms [28], but the immobilization and retention rates depend mainly on soil properties [29-30].

\section{Physical and Chemical Properties of Soils}

The mineral composition of the $<2 \mu \mathrm{m}$ fraction of the soils shows in most cases a predominance of kaolin- ite, except for two samples ( 3 and 4), where smectite was the dominant mineral (Table 2). It should be mentioned that samples $1,2,5,6$, and 8 contained additionally illite (mostly in mixed layered smectite-illite), in contrast to 3, 4, and 7, where illite was not identified. Calcite (Cc), goethite $(\mathrm{Gt})$, and quartz $(\mathrm{G})$ have been also observed in samples 2,7 , and 8 , respectively. The status of these soils implies that they were much more anthropogenic than geogenic, hence their mixed and multiphasic mineralogical character [31].

This mineralogy organizes the soils into two operational groups: kaolinite and smectite. The first one involves soils characterized by values of the cation exchange capacity (CEC) spreading within the range 1.4-9.9 $\mathrm{cmol}_{(+)} \mathrm{kg}^{-1}$, contrarily to the smectite group with the range $15.1-26.8 \mathrm{cmol}_{(+)} \mathrm{kg}^{-1}$. This discrepancy is intrinsically related to the occurrence of layered minerals of the type 1:1 (specifically for kaolinite) and 2:1 (for the smectite). According to Hong et al. [32], the interlayer of these clays determines their reactivity, i.e., sorption/desorption power as well as the capacity for shrinking and swelling. These properties predestinate and are fundamental for forecasting the buffering capacities of soils.

It should be mentioned that the kaolinite group prevailed by representing $75 \%$ of all tested soils as compared to $25 \%$ for the smectite one. Therefore, it is expected that $3 / 4$ of soils within the investigated area should potentially reflect the relatively weak $\mathrm{Zn}$ retention. Ratings for the cation exchange capacity (CEC) as suggested by Hazelton and Murphy [21] imply that the kaolinite group exhibited very low to low buffering properties, in contrast to the smectite (moderate to high). This stresses the fact that $\mathrm{Zn}$ is weakly to moderately retained by soils and should be more easily released (mobile). Next, in terms of retention mechanisms this process may be related to the decrease in the number of charges on soil colloids, a mechanism hampering the adsorption of $\mathrm{Zn}$ on exchange sites [33]. These geochemical conditions will favor zinc mobility and then raise its phytotoxicity.

It is generally accepted that among the various properties that regulate $\mathrm{Zn}$ availability, factors such as soil particles and organic matter as well as $\mathrm{pH}$ play a key role [34]. For soils investigated in the current study (Table 2), it was observed that sand prevailed with more than $60 \%$ of all soil fractions. Taking into consideration the fact that clay and silt fractions are much more responsible than sand for regulating $\mathrm{Zn}$ chemistry in the soils, summarizing their levels should give values indicative of weak or strong soil buffering capacities. This view is in line with the approach reported by Diatta et al. [35], which presented such practical and reasonable possibilities. In the case of data reported in Table 2, only three soils, representing the so-called smectite group, exhibited a [Silt + Clay] value $>500 \mathrm{~g} \mathrm{~kg}^{-1}$, as compared to the kaolinite group, where the contents of both fractions fluctuated within the range 180-400 $\mathrm{g} \mathrm{kg}^{-1}$. The mineralogical composition along with the contents of silt and clay were operating as the basic factors, but not the only ones, potentially shaping $\mathrm{Zn}$ behavior of the tested soils. 
Table 2. Selected physical and chemical properties of investigated soils.

\begin{tabular}{|c|c|c|c|c|c|c|c|c|c|}
\hline \multirow{3}{*}{ Sample No } & \multirow{3}{*}{ Mineralogy $^{\mathrm{a}}$} & \multicolumn{3}{|c|}{ Soil particles } & \multirow{3}{*}{$\mathrm{C}_{\text {org }}^{\mathrm{b}}$} & \multicolumn{2}{|c|}{$\mathrm{pH}$} & \multirow{3}{*}{$\begin{array}{c}\mathrm{EC}^{\mathrm{c}} \\
\left(\mu \mathrm{S} \mathrm{cm}^{-1}\right)\end{array}$} & \multirow{3}{*}{$\begin{array}{c}\mathrm{CEC}_{\mathrm{ef}}^{\mathrm{d}} \\
\left(\mathrm{cmol}_{(+)} \mathrm{kg}^{-1}\right)\end{array}$} \\
\hline & & Sand & Silt & Clay & & \multirow{2}{*}{$\mathrm{H}_{2} \mathrm{O}$} & \multirow{2}{*}{$\mathrm{CaCl}_{2}$} & & \\
\hline & & \multicolumn{3}{|c|}{$\left(\mathrm{g} \mathrm{kg}^{-1}\right)$} & & & & & \\
\hline 1 & Kaolinite $>$ Illite & 820 & 84 & 96 & 5.5 & 6.7 & 5.7 & 34.7 & 1.4 \\
\hline 2 & Kaolinite $>$ Illite & 760 & 148 & 92 & 9.1 & 6.2 & 4.9 & 41.6 & 1.8 \\
\hline 3 & Smectite $>$ Kaolinite & 248 & 488 & 264 & 15.5 & 7.6 & 7.2 & 189.1 & 26.8 \\
\hline 4 & Smectite $>$ Kaolinite & 500 & 240 & 260 & 20.0 & 7.5 & 7.1 & 128.5 & 15.1 \\
\hline 5 & Kaolinite $>$ Illite & 600 & 268 & 132 & 11.2 & 6.3 & 5.6 & 68.3 & 5.4 \\
\hline 6 & Kaolinite $>$ Illite & 784 & 132 & 84 & 7.5 & 6.8 & 5.9 & 72.3 & 5.9 \\
\hline 7 & Kaolinite $>$ Smectite & 462 & 410 & 128 & 31.0 & 6.0 & 4.6 & 65.7 & 9.9 \\
\hline 8 & Kaolinite $>$ Illite & 640 & 275 & 85 & 165.1 & 4.5 & 3.4 & 134.4 & 2.5 \\
\hline
\end{tabular}

a: Refer to Materials and methods; ${ }^{\mathrm{b}}$ : Organic carbon; ${ }^{\mathrm{c}}$ : Electrical conductivity; ${ }^{\mathrm{d}}$ : Effective cation exchange capacity

Soils within the area impacted by the smelter were characterized by mostly slightly acidic to acidic reactions, except for site Nos. 3 and 4 representing the smectite group (mean $\left.\mathrm{pH}_{\mathrm{CaCl} 2}=7.15\right)$. Such soil reaction may increase the mobility availability of $\mathrm{Zn}$, particularly when $75 \%$ of investigated soils exhibited $\mathrm{pH}_{\mathrm{CaCl} 2}$ below 6.0. The extent of zinc speciation depends on stability constants of the species formed, ionic strength, $\mathrm{pH}$, and the type and relative concentrations of cations and anions in the solution [36]. Data reported by Alloway [37] showed that zinc ions such as $\mathrm{Zn}^{2+}, \mathrm{ZnCl}^{+}$, and $\mathrm{ZnOH}^{+}$(or also complexed with organic matter) occur in the soil solution where $\mathrm{pH}$ is below 6.5. The mobility and further availability of $\mathrm{Zn}$ compounds have undergone experimental measurements, which allowed the formulation of equilibrium constants [38-40]. The latter ones outlined the solubility of $\mathrm{Zn}$ as directly proportional to the square of proton activity as follows: soil- $\mathrm{Zn}+2 \mathrm{H}^{+} \leftrightarrow \mathrm{Zn}^{2+}$, then their results generated a $\log \mathrm{K}^{\mathrm{o}}$ for this equation of 5.8. The transformation of this equilibrium reaction gives a $\log \left(\mathrm{Zn}^{2+}\right) \leftrightarrow 5.8-2 \mathrm{pH}$, implying that the solubility and therefore $\mathrm{Zn}$ availability increase with a decrease in soil $\mathrm{pH}$ [41]. This was the additional key factor decidedly controlling geochemical processes of $\mathrm{Zn}$ compounds and their further transfer to other environmental compartments [42-43]. These factors are the geo-environmental barriers efficiently reducing metals mobility and their further uptake by plants [40, 44-45].

Changes in Zn geochemistry are also regulated by the quantity and quality of organic matter [46]. Data listed in Table 2 show that the content of organic carbon varies from 5.5 to $165.1 \mathrm{~g} \mathrm{~kg}^{-1}$, with a mean of $33.1 \mathrm{~g} \mathrm{~kg}^{-1}$. When considering the value $165.1 \mathrm{~g} \mathrm{~kg}^{-1}$ as an outlier, the mean site $\mathrm{C}_{\text {org }}$. content changes to $14.3 \mathrm{~g} \mathrm{~kg}^{-1}$. The ranges suggested by Sequi de Nobili [47] i.e., $\mathrm{C}_{\text {org }}<5.8 \mathrm{~g} \mathrm{~kg}^{-1}$ (very low); 5.8-10.4 $\mathrm{g} \mathrm{kg}^{-1}$ (low), 11-14.5 $\mathrm{g} \mathrm{kg}^{-1}$ (moderate), and $\mathrm{C}_{\text {org }}>14.5 \mathrm{~g} \mathrm{~kg}^{-1}$ (high) indicate that the site investigated in the current study may be classified as moderately rich in organic matter. Therefore, the formation of metal-organic complexes (for instance Zn-Organic matter), [45, 48-49] may proceed less efficiently. The moderate organic matter content along with soil mineralogy (dominated mostly by kaolinite and illite minerals) and particle size with the prevalence of sand confirm the concern of $\mathrm{Zn}$ mobility and hence the emergence of potential site-specific phytotoxicity.

\section{Zinc Content and its Fractions in the Investigated Zone}

Ecological risk assessment is a fundamental consideration for evaluating the effects of metal-polluted soils. The simulation of ecologically relevant conditions in the pedosphere requires the application of targeted soil tests discriminating mobile and mobilisable metal fractions [50]. The evaluation of zinc geo-bio-availability has been undertaken through three operational steps, where total $\left(\mathrm{Zn}_{\text {Total }}\right)$ as well as reactive $\left(\mathrm{Zn}_{\text {Reac }}\right)$ and bioavailable $\left(\mathrm{Zn}_{\text {Bio }}\right)$ $\mathrm{Zn}$ forms were determined (Table 3). The $\mathrm{Zn}_{\text {Total }}$ parameter should be considered basically as to be used for site state information about contamination and/or pollution as well as geochemical background purposes [51]. It does not provide details related to the geochemical behavior and further fate of $\mathrm{Zn}$ compounds [50].

The highest level of $\mathrm{Zn}_{\text {Total }}$ occurred at site No. 3 and amounted to $3,912.0 \mathrm{mg} \mathrm{kg}^{-1}$, but the soil collected at site No. 4 exhibited a content quite half lower, i.e., $1,245.0 \mathrm{mg} \mathrm{kg}^{-1}$. For the remaining sites, $\mathrm{Zn}_{\text {Total }}$ varied within the range $177.0-472.5 \mathrm{mg} \mathrm{kg}^{-1}$. According to Kabata-Pendias and Pendias [52], the background level for Poland is fixed at $75.0 \mathrm{mg} \mathrm{kg}^{-1}$, which means that this value was exceeded from 2.5 to 52 times. Next, in the case of natural $\mathrm{Zn}$ content (i.e., geochemical background), the suggested value amounts to $30.0 \mathrm{mg} \mathrm{kg}^{-1}$ [53]. The state of soil contamination evaluated on the basis of this value revealed $\mathrm{Zn}$ concentration exceeding on average 30 times (from 6 to 130 times) for the whole area of study. 
Table 3. Total $\mathrm{Zn}$ content $\left(\mathrm{Zn}_{\text {Total }}\right)$, reactive $\left(\mathrm{Zn}_{\text {Reac }}\right)$ and bioavailable $\left(\mathrm{Zn}_{\mathrm{Bio}}\right)$ forms in investigated soils (mean, $\left.\mathrm{n}=5\right)$.

\begin{tabular}{|c|c|c|c|}
\hline \multirow{2}{*}{ Sample No } & Total $\left(\mathrm{Zn}_{\text {Total }}\right)$ & $0.11 \mathrm{~mol} \mathrm{CH}_{3} \mathrm{COOH}\left(\mathrm{Zn}_{\text {Reac }}\right)$ & $0.10 \mathrm{~mol} \mathrm{NaNO}_{3}\left(\mathrm{Zn}_{\text {Bio }}\right)$ \\
\cline { 2 - 4 } & \multicolumn{3}{|c|}{$\left(\mathrm{mg} \mathrm{kg}^{-1}\right)$} \\
\hline 1 & $472.5 \pm 159.3 *$ & $302.4 \pm 153.7$ & $28.50 \pm 2.47$ \\
\hline 2 & $418.5 \pm 296.0$ & $240.9 \pm 248.1$ & $27.67 \pm 7.59$ \\
\hline 3 & $3,912.0 \pm 1,224.3$ & $1,135.0 \pm 454.7$ & $14.66 \pm 1.52$ \\
\hline 4 & $1,245.0 \pm 793.2$ & $493.9 \pm 297.8$ & $5.19 \pm 0.55$ \\
\hline 5 & $246.0 \pm 31.1$ & $80.2 \pm 18.8$ & $2.30 \pm 0.39$ \\
\hline 6 & $369.0 \pm 324.3$ & $66.8 \pm 35.4$ & $0.43 \pm 0.06$ \\
\hline 7 & $177.0 \pm 62.2$ & $52.1 \pm 18.5$ & $0.15 \pm 0.02$ \\
\hline 8 & $204.0 \pm 60.6$ & $68.2 \pm 21.8$ & \\
\hline
\end{tabular}

*mean values \pm standard deviation

These data clearly confirm the long-term cumulative $\mathrm{Zn}$ emissions as illustrated on Fig. 1 and the fact that the pollution occurred mostly at the upper soil layers. The latter ones are the pedo-rhizosphere zones for the dynamic growth of pine rootlets [54], which in turn take up and accumulate $\mathrm{Zn}$ compounds.

Among multiple procedures reported for evaluating and forecasting the impact of trace elements, including $\mathrm{Zn}$ (among others) on the biota, the BCR method [24] is frequently applied. For the current study, only the first fraction, i.e., $\mathrm{Zn}_{\text {Reac }}$ was considered (Table 3). The amounts of $\mathrm{Zn}$ extracted by this test represented from 18 to $64 \%$ of $\mathrm{Zn}_{\text {Total }}$ (mean $34.6 \%$ ), which implies that zinc was relatively weakly bound and retained by investigated soils. The behavior of $\mathrm{Zn}$ compounds under such conditions is intrinsically related to the mineralogical composition, where kaolinite occurred in all tested soil and next as the dominating mineral, except for soils 3 and 4 (Table 2 ). The buffering properties of the latter ones are very extended due to the joint effects off smectite as well as $\mathrm{pH}$ and organic matter. These parameters decidedly control the mobility of metallic elements and simultaneously are responsible for their relatively low solution activity [55]. As a matter of fact, it should be mentioned that $\mathrm{Zn}$ is much more mobile than frequently reported heavy metals, for instance $\mathrm{Cu}, \mathrm{Pb}, \mathrm{Ni}$, and $\mathrm{Cd}$ [56]. But the respectively high concentrations of $\mathrm{Zn}$ in the reactive fractions $\left(\mathrm{Zn}_{\text {Reac }}\right)$ as listed in Table 3 did not confirm this rule, indicating an enhanced mobility and potential phytotoxicity.

The tangible harmful effects that could be expected from $\mathrm{Zn}$ were those evaluated on the basis of the bioavailable fraction $\left(\mathrm{Zn}_{\mathrm{Bio}}\right)$. According to Gupta and Häni [23] and Gupta and Aten [57], the threshold value for $\mathrm{Zn}$ toxicity to microorganisms [6] and plants is $0.50 \mathrm{mg} \mathrm{kg}^{-1}$. This level was exceeded in almost all investigated soils, except for Nos. 7 and 8. The mean $\mathrm{Zn}_{\text {Bio }}$ content for the whole area amounted to $12.5 \mathrm{mg} \mathrm{kg}^{-1}$, representing ca. $1.42 \%$ of $\mathrm{Zn}_{\text {Total }}$. On the other hand, the risk of $\mathrm{Zn}$-induced biological toxicity was raised 25 times $\left(12.5 \mathrm{mg} \mathrm{kg}^{-1}\right.$ : $0.5 \mathrm{mg} \mathrm{kg}^{-1}$ ), but spread within the range from 0.3 to even
57 times. Such an impact of Zn-contaminated soil along with additional air pollution pertinently participates in the deterioration of forest stands [4].

\section{Geochemical Evaluation of Zn Reactivity}

The reaction of metallic ions with soil colloids is intermediated by functional groups, which generate charges enabling sorption and retention mechanisms to proceed properly. The resulting deprotonation process activated by metal binding should be a measure of potential geochemical reactivity and mobility of metals in the soil environment $[26,58]$. This approach was outlined throughout the proton generation capacity $(\alpha)$ index (Table 4 ) with the values calculated for $\mathrm{pH}_{\mathrm{H} 2 \mathrm{O}}$ and $\mathrm{pH}_{\mathrm{CaCl} 2}$ and both $\mathrm{Zn}$ forms, i.e., $\mathrm{Zn}_{\text {Bio }}$ and $\mathrm{Zn}_{\text {Reac }}$. The results revealed, that the $\mathrm{Zn}_{\text {Bio }}$ fraction was characterized by the highest values of $\alpha$ as compared to $\mathrm{Zn}_{\text {Reac }}$, irrespective of soil $\mathrm{pH}$. This finding is in line with data reported by Diatta and Chudzińska [43], implying that the reactions of zinc ions with active sites on colloid surfaces as well as with functional groups leads to the deprotonation mechanism. Consequently, this process increases the activity of $\mathrm{Zn}^{2+}$ in the soil solution. The initiated geochemical mechanism "secures" zinc ions and other metals against sorption by keeping them in relative solution activity. The $\alpha$ indices for the reactive $\mathrm{Zn}$ form $\left(\mathrm{Zn}_{\text {Reac }}\right)$ were markedly low as compared to $\mathrm{Zn}_{\mathrm{Bio}}$. This is particularly worth reporting due to the chemical characteristics of tests applied for extracting both forms of $\mathrm{Zn}$. For $\mathrm{Zn}_{\text {Reac, }}$, the concentrations of $\mathrm{H}^{+}$incorporated with the use of the $0.11 \mathrm{~mol} \mathrm{CH}_{3} \mathrm{COOH} \mathrm{dm}{ }^{-3}$ test were high enough to hamper the geochemical process of proton generation, resulting in $\mathrm{Zn}$ sorption and retention.

This is clearly reflected by the relationships established for the pairs $K_{d}$ (distribution coefficient) versus $\mathrm{pH}$ of investigated soils. The mean values of $\alpha$ (for the whole zone impacted by the smelter) revealed that this proton generation activity for $\mathrm{Zn}_{\mathrm{Bio}}$ was 60 times higher than that observed in the case of $\mathrm{Zn}_{\text {Reac }}$ - proof of a controlling effect of $\mathrm{pH}$ on $\mathrm{Zn}$ soil solution chemistry. Investigations 
Table 4. Evaluation of proton generation $(\alpha)$ and retention $(\beta)$ capacities for bioavailable $\left(\mathrm{Zn}_{\text {Bio }}\right)$ and reactive $\left(\mathrm{Zn}_{\text {Reac }}\right) \mathrm{Zn}$ forms.

\begin{tabular}{|c|c|c|c|c|}
\hline \multirow{2}{*}{ Test } & \multirow{2}{*}{$\mathrm{pH}$} & $\alpha$ & $\beta$ & \multirow{2}{*}{$\mathrm{r}^{*}$} \\
\hline & & $\left(\mathrm{mol} \mathrm{H}^{+} \mathrm{mol}^{-1} \mathrm{Zn}^{2+}\right)$ & $\left(\mathrm{mol}_{(-)} \mathrm{kg}^{-1}\right.$ soil $)$ & \\
\hline \multirow{2}{*}{$0.10 \mathrm{~mol} \mathrm{NaNO}_{3} \mathrm{dm}^{-3}\left(\mathrm{Zn}_{\mathrm{Bio}}\right)$} & $\mathrm{H}_{2} \mathrm{O}$ & 0.481 & 0.85 & 0.513 \\
\hline & $\mathrm{CaCl}_{2}$ & 0.401 & 0.020 & 0.532 \\
\hline \multirow{2}{*}{$0.11 \mathrm{~mol} \mathrm{CH}_{3} \mathrm{COOH} \mathrm{dm}{ }^{-3}\left(\mathrm{Zn}_{\text {Reac }}\right)$} & $\mathrm{H}_{2} \mathrm{O}$ & 0.004 & 2.09 & 0.026 \\
\hline & $\mathrm{CaCl}_{2}$ & 0.011 & 2.00 & 0.092 \\
\hline
\end{tabular}

*Coefficient of correlation

carried out by Benjanin and Leckie [58] pointed out the process of $\mathrm{Zn}$ sorption/immobilization resulting in about $75 \%$ of more $\mathrm{H}^{+}$generation as compared to metals such as $\mathrm{Cd}, \mathrm{Cu}$, and $\mathrm{Pb}$. Others, for instance Christensen et al. [59], have indicated at $40 \%$, respectively, but with reference to $\mathrm{Cd}, \mathrm{Co}$, and $\mathrm{Ni}$.

The retention capacity $(\mathrm{RC})$ index $(\beta)$ expresses the degree at which the soil environment is capable of retaining or immobilizing metallic elements $[43,58]$. Among investigated $\mathrm{Zn}$ forms, only in the case of $\mathrm{Zn}_{\text {Reac }}$ were the highest concentrations of soil charges (on average $2.05 \mathrm{~mol} \mathrm{~kg}^{-1}$ ) responsible for sorption as well as retention observed. This is an important characteristic of the test $0.11 \mathrm{~mol} \mathrm{CH}_{3} \mathrm{COOH} \mathrm{dm}{ }^{-3}$, since the extracted $\mathrm{Zn}$ amounts were characterized simultaneously by relatively high activity $\left(\mathrm{Zn}_{\text {Bio }}\right)$ as well as stability $\left(\Delta=\mathrm{Zn}_{\text {Reac }}-\mathrm{Zn}_{\text {Bio }}\right)$. These results confirm earlier reports about increased mobility of $\mathrm{Zn}$ due to its slightly weak retention by soils [60], thus creating a threat for the biota - particularly the investigated Scots pine trees.

\section{Impact of $\mathrm{Zn}$ on $\mathrm{Mg}$ and $\mathrm{Fe}$ Concentrations in Scots Pine Needles}

Zinc, magnesium, and iron play key roles in the efficient course of photosynthesis, therefore these elements can constitute phytochemical indicators of plant resistance or sensitivity to industrial pollution - particularly Scots pine [61-63]. Next, the excess of $\mathrm{Zn}$ and most frequently the deficiency of Fe in plants hamper the photosynthesis process, which strongly disturbs plant growth [13-14]. The assessment of the degree of Scots pine (Pinus sylvestris) needles contamination by $\mathrm{Zn}$ was carried out on two species, i.e., tolerant (T) and sensitive (S). Data listed in Table 5 point to a high degree of needle contamination as impacted by the $\mathrm{Zn}$-Smelter.

Moreover, it should be mentioned that the concentrations of $\mathrm{Zn}, \mathrm{Fe}$, and $\mathrm{Mg}$ in the tolerant $(\mathrm{T})$ pine are higher as compared to the sensitive (S) species, irrespective of the age of the needles. Data averaged for the whole pine populations showed that in the case of the T species, the 2-year-old needles accumulated 21.9, 38.2, and 13.6\% more $\mathrm{Zn}, \mathrm{Fe}$, and $\mathrm{Mg}$, respectively, with reference to the 1 -year-olds. In the case of the $\mathrm{S}$ species, the trend follows similarly the proportions $12.4,48.8$, and $7.3 \%$.

These data decidedly show that $\mathrm{Fe}$ was most accumulated by 2-year-old needles, irrespective of investigated species. Therefore, Fe should be considered a "strategic survival element" for both Scots species under high $\mathrm{Zn}$ pollution conditions. In their study, Başlar et al. [63] reported a similar trend, but induced by $\mathrm{Cu}$ concentrations in the case of Pinus brutia. The highest accumulation of $\mathrm{Zn}$ and $\mathrm{Mg}$, particularly in the case of the tolerant (T) pine, may be related to physiological functions, where enzymatic activities are basically controlled by both elements.

The response of both pine species to high $\mathrm{Zn}$ contents in needles was illustrated by a similar course in the increase of $\mathrm{Mg}$ and $\mathrm{Fe}$ concentrations (Figs. 2a-b, 3a-b). It should be noted that the effect of $\mathrm{Zn}$ in plants is commonly agreed to be positive (as a micronutrient), but it is adverse in the case of pollution, as for the currently investigated

Table 5. Optimal ranges of $\mathrm{Zn}, \mathrm{Fe}$ and $\mathrm{Mg}$ concentrations in dry matter of Scots pine needles $(64)^{\mathrm{a}}$ and data of the current study ${ }^{\mathrm{b}}(\mathrm{n}=24$ for each species and age of needles).

\begin{tabular}{|c|c|c|c|c|c|}
\hline \multirow{4}{*}{ Element } & \multirow{3}{*}{ Ranges $^{\mathrm{a}}$} & \multicolumn{2}{|c|}{ Tolerant $(\mathrm{T})^{\mathrm{b}}$} & \multicolumn{2}{|c|}{ Sensitive $(\mathrm{S})^{\mathrm{b}}$} \\
\hline & & \multicolumn{4}{|c|}{ Pine needles } \\
\hline & & 1-year old & 2-year old & 1-year old & 2-year old \\
\hline & \multicolumn{5}{|c|}{$\mathrm{mg} \mathrm{kg}^{-1}$} \\
\hline $\mathrm{Zn}$ & $17-88$ & $347 \pm 85^{c}$ & $423 \pm 101$ & $322 \pm 87$ & $362 \pm 82$ \\
\hline $\mathrm{Fe}$ & $100-850$ & $55 \pm 13$ & $76 \pm 29$ & $41 \pm 16$ & $61 \pm 24$ \\
\hline $\mathrm{Mg}$ & $300-1400$ & $323 \pm 108$ & $367 \pm 104$ & $259 \pm 108$ & $278 \pm 72$ \\
\hline
\end{tabular}

${ }^{\mathrm{c}}$ mean values \pm standard deviation 
a)

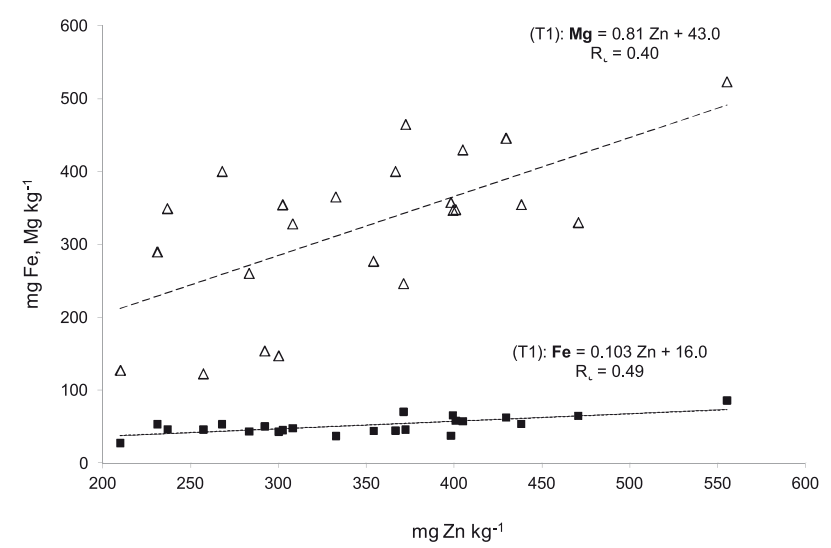

b)

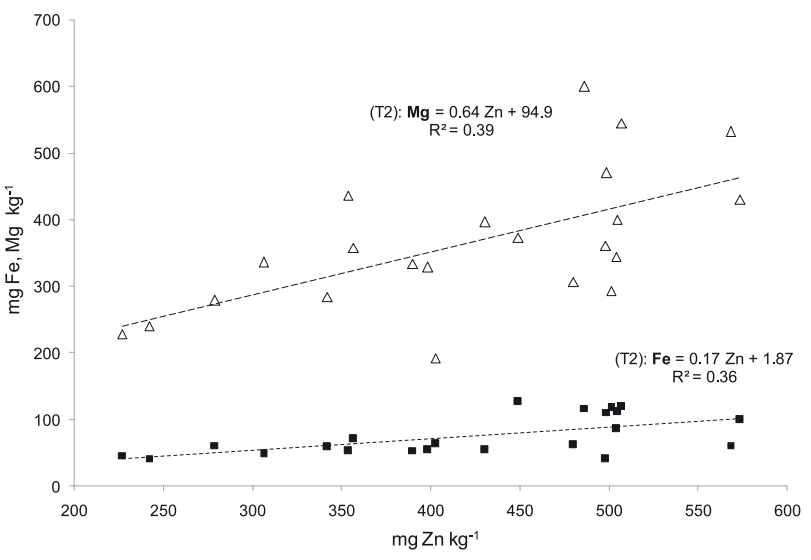

Fig. 2. a) relationship between $\mathrm{Zn}$ versus $\mathrm{Mg}$ and Fe concentrations in 1-year-old (T1) Scots pine needles of the tolerant (T) species, b) relationship between $\mathrm{Zn}$ versus $\mathrm{Mg}$ and Fe concentrations in 2-year-old (T2) Scots pine needles of the tolerant (T) species.

needles. The evaluation made on the basis of the coefficients of determination $\left(\mathrm{R}^{2}\right)$ showed that the increase in $\mathrm{Zn}$ concentrations induced the strongest accumulation of $\mathrm{Mg}$ in the tolerant (T) species, both for 1- and 2-year-old needles as compared to the sensitive (S) species. A reverse trend was observed in the case of Fe. Therefore, it can be formulated that $\mathrm{Mg}$ constitutes a basic element alleviating the negative effects of $\mathrm{Zn}$ in the tolerant Scots pine, but the survival of the sensitive pine depended much more on adequate $\mathrm{Fe}$ concentrations in the needles. This is proven by a very high increase $(48.8 \%)$ of Fe concentrations in the $\mathrm{S}$ species compared to $\mathrm{T}$. The needle contents of $\mathrm{Mg}$ and $\mathrm{Fe}$ for both pines confirmed their biological strategy for survival adaptation. This process is strictly related to the whole Scots pine fresh biomass [65] as the basic receptor of environmental stresses. The transfer of $\mathrm{Zn}$ ions from the soil environment to plants still remains the basic source of maintaining its high concentrations in the needles, since air emissions have quite ceased from 1996 (Fig.1). Next, the plant accumulated $\mathrm{Zn}$ at crucial years of emissions may be considered as an additional timeconstant source due to the evergreen vegetative cycle of Scots pine. a)

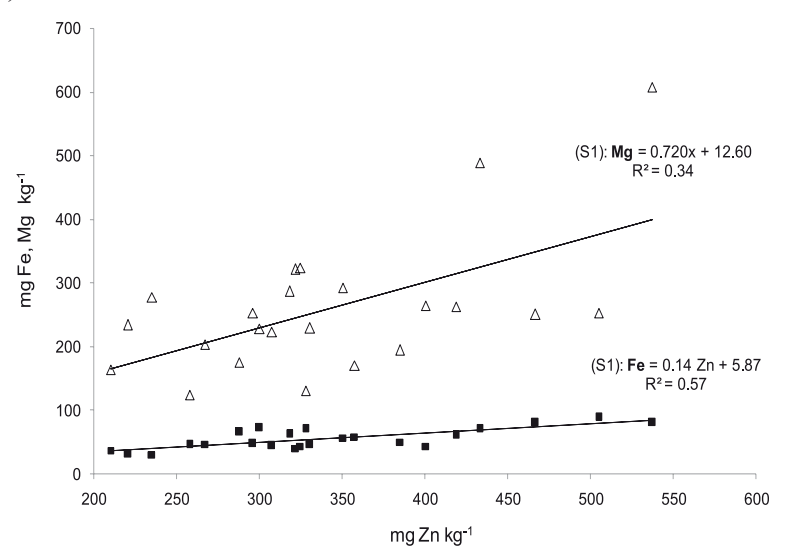

b)

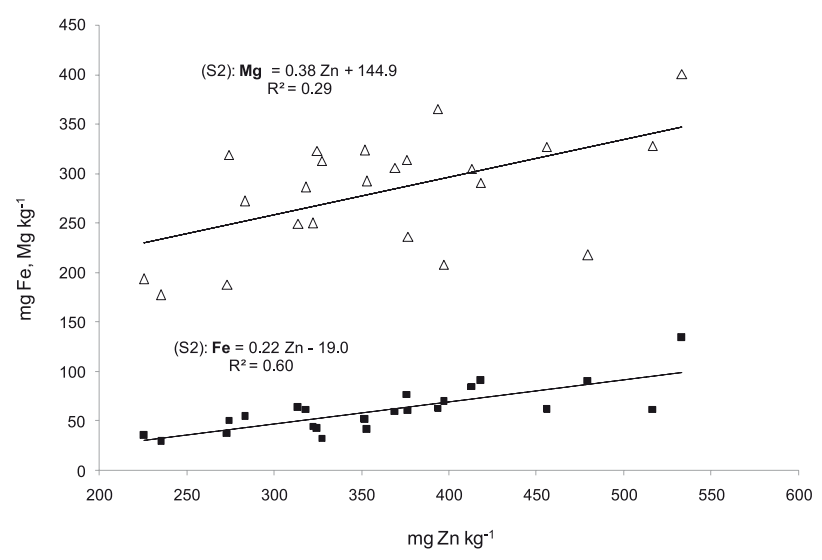

Fig. 3.a) relationship between $\mathrm{Zn}$ versus $\mathrm{Mg}$ and Fe concentrations in 1-year-old (S1) Scots pine needles of the sensitive (S) species, b) relationship between $\mathrm{Zn}$ versus $\mathrm{Mg}$ and $\mathrm{Fe}$ concentrations in 2-year-old (S2) Scots pine needles of the sensitive (S) species.

\section{Conclusions}

1. The mineralogical composition of the $<2 \mu \mathrm{m}$ revealed the occurrence and prevalence of kaolinite in all soils, except for two samples (i.e., 3 and 4), where smectite was the dominant mineral. This mineral structure was decisive in $\mathrm{Zn}$ geochemistry, but assisted by $\mathrm{pH}$ and organic matter.

2. The contamination state evaluated on the basis of the geochemical background value (30.0 mg Zn kg-1) revealed that this value was exceeded $c a .30$ times within the investigated zone.

3. Amounts of reactive $\left(\mathrm{Zn}_{\text {Reac }}\right) \mathrm{Zn}$ forms represented from 18 to $64 \%$ of $\mathrm{Zn}_{\text {Total }}$ (on average $34.6 \%$ ), thus indicating relatively weak $\mathrm{Zn}$ retention by soils.

4. The values of proton generation capacity $(\alpha)$ for the whole zone show that $\boldsymbol{\alpha}$ for the bioavailable $\mathrm{Zn}$ fraction $\left(\mathrm{Zn}_{\mathrm{Bio}}\right)$ was 59 time higher as compared to the reactive fraction $\left(\mathrm{Zn}_{\text {Reac }}\right)$. This implies a strong influence of soil $\mathrm{pH}$ on $\mathrm{Zn}$ ion activity.

5. For the tolerant (T) Scots pine, the 2-year-old needles accumulated $21.9,38.2$, and $13.6 \%$ much more $\mathrm{Zn}, \mathrm{Fe}$, and $\mathrm{Mg}$ as compared to 1-year-old needles. 
The sensitive (S) species exhibited the following trend, i.e., 12.4, 48.8, and 7.3\%, respectively.

6. Iron concentrations in needles may be regarded as a "strategic survival element" for both pine species growing under conditions of high $\mathrm{Zn}$ pollution.

7. Amounts of $\mathrm{Zn}$ accumulated by Scots pines in crucial years of metallurgical emissions may be considered as an additional time-constant source due to the evergreen vegetative life cycle.

\section{Acknowledgements}

This study was financially supported by the Polish National Science Centre (grant No. NN 305058440), titled "Comparison of micro-evolutional processes taking place in the two bioindicative species; Pinus nigra Arn. and Pinus sylvestris L. growing in a heavy polluted environment."

\section{References}

1. KLIMEK B. Effect of long-term zinc-pollution on soil microbial community resistance to repeated contamination. Bull. Environ. Contam. Toxicol. 88, 617, 2012.

2. BUSSINOW M., SARAPATKA B., DLAPA P. Chemical degradation of forest soil as a result of polymetallic ore mining activities. Pol. J. Environ. Stud. 21 (6), 1551, 2012.

3. NIKOLAIDIS C., ZAFIRIADIS I., MATHIOUDAKIS V., CONSTANTINIDIS T. Heavy Metal Pollution Associated with an Abandoned Lead-Zinc Mine in the Kirki Region, NE Greece. Bull. Environ. Contam. Toxicol. 85 (3), 307, 2010.

4. DISANTE K., FUENTES D., CORTINA J. Sensitivity to zinc of Mediterranean woody species important for restoration. Sci. Total Environ. 408, 2216, 2010.

5. AZOUZI R., CHAREF A., HAMZAOUI A. Assessment of effect of $\mathrm{pH}$, temperature and organic matter on zinc mobility in a hydromorphic soil. Environ. Earth Sci. 74 (4), 2967, 2015.

6. RUTKOWSKA B., SZULC W., BOMZE K., GOZDOWSKI D., SPYCHAJ-FABISIAK E. Soil factors affecting solubility and mobility of zinc in contaminated soils. Int. J. Environ. Sci. Technol. 12, 1687, 2015.

7. RODELLA A.A., CHIOU D.G. Copper, zinc and manganese mobilization in a soil contaminated by metallurgy waste used as micronutrient source. Commun. Soil Sci. Plant Anal. 40, 1634, 2009.

8. MANARA A. Plant Responses to heavy metal toxicity. In. A. Furini (ed.), Plants and Heavy Metals, Springer Briefs in Biometals. ISBN 98-94-007-4440-0, 27, 2012.

9. MARKERT B., BREURE A., ZECHMEISTER H., (eds.) Bioindicators \& Biomonitors. Principles, Concepts and Applications. Elsevier, Amsterdam, 2003.

10. COMMUNICATION FROM THE COMMISSION TO THE EUROPEAN PARLIAMENT, the European Economic and Social Committee and the Committee of the Regions. A new EU Forest Strategy: for forests and the forest-based sector; $\operatorname{COM}(2013) 659$ final. Brussels 20.9.2013

11. PARZYCH A., JONCZAK J. Pine needles (Pinus sylvestris 1.) as bioindicators in the assessment of urban environmental contamination with heavy metals. J. Ecol. Eng., 15 (3), 29, 2014.
12. GEROLD-ŚMIETAŃSKA I. Trends in changes of forest stands as observed at perennial experimental sites in the vicinity of the Zinc Smelter of the Miasteczko Śląskie. $\mathrm{PhD}$ thesis, Katowice, Uniwersytet Śląski, 124, [n Polish], 2007.

13. CREGG B. Conifer nutrition. Conifer Corner. Michigan Stet University (MSU), Soil and Plant Nutrient Laboratory, 42, 2005.

14. HUETTL R.F. Mg deficiency - a "new" phenomenon in declining forest - symptoms and effects, causes, recuperation. In Huettl R.F. and Mueller Dombois D. (eds): Forest decline in the Atlantic and Pacific Region, Springer-Verlag, Berlin Heidelberg, 97, 1993.

15. WOO S.Y. Forest decline of the world: A linkage with air pollution and global warming. Afr. J. Biotechnol. 8 (25), 7409, 2009

16. SOIL SURVEY STAFF. Soil survey field and laboratory methods manual. Soil Survey Investigations Rep. 51, Version 1.0. R. Burt (ed.) USDA, Natural Resources Conserv. Serv., Washington, DC, 2009.

17. VALENTE S D.M., DE QUEIROZ D.M., DE CARVALHO P.F., Terra SANTOS N., SANTOS F.L. The relationship between apparent soil electrical conductivity and soil properties. Rev. Ciênc. Agron. 43 (4), 683, 2012.

18. RECOMMENDED CHEMICAL SOIL TEST PROCEDURES FOR THE NORTH CENTRAL REGION. North Central Regional Research Publication No. 221 (Revised), 76, 2012.

19. WANG X., WANG J., ZHANG J. Comparisons of three methods for organic and inorganic carbon in calcareous coils of Northwestern China. PLoS ONE 7 (8), e44334. doi:10.1371/journal.pone.0044334, 2012.

20. APRILE F., LORANDI R. Evaluation of Cation Exchange Capacity (CEC) in Tropical Soils Using Four Different Analytical Methods. J. Agric. Sci. 4 (6), 278, 2012.

21. HAZELTON P., MURPHY B. Interpreting soil test results. What do all the numbers mean? Pam Hazelton and NSW Department of Natural Resources, 160, 2007.

22. TARAŠKEVIČIUS R., ZINKUTÉ R., STAKĖNIENE R., RADAVIČIUS M. Case study of the relationship between aqua regia and real total contents of harmful trace elements in some European soils. J. Chem. 2013 Article ID 678140:12013.

23. GUPTA S.K., HÄNI H. Méthode pour la détermination dans les sols les concentrations de métaux lourds disponibles pour les plantes et les microorganismes et vérification dans les zones contaminées, Rapport final COST 681, Nr 2. (FAC), 1989.

24. LI Q. Soil Remediation: Metal Leaching from Contaminated Soil through the Modified BCR Sequential Extraction Procedure. Master of Science Thesis, Department of Civil and Environmental Engineering, Chalmers University of Technology, Gothenburg, Sweden., 34, 2012.

25. ŚRODOŃ J. Identification and Quantitative Analysis of Clay Minerals. Chapter 2.2 in Handbook of Clay Science, Developments in Clay Science 5, F. Bergaya and G. Lagaly, eds., Elsevier, 25, 2013.

26. KURBATOV M.H., KURBATOV G.B., WOOD J.D. Isothermal adsorption of cobalt from dilute solutions. J. Phys. Chem. 55, 1170, 1951.

27. CHUDZINSKA E., DIATTA J., WOJNICKA-PÓŁTORAK A. Adaptation strategies and referencing trial of Scots and black pine populations subjected to heavy metal pollution. Environ. Sci. Pollut. R., 21 (3), 2165, 2014.

28. VODYANITSKII Y.N. Zinc forms in soils. Eurasian Soil Science 43 (3), 269, 2010. 
29. RIM A., ABDELKRIM C., AHMED H. Assessment of effect of $\mathrm{pH}$, temperature and organic matter on zinc mobility in a hydromorphic soil. Environ. Earth Sci., 74 (4), 2967, 2015.

30. JANKIEWICZ B., ADAMCZYK D. Assessing heavy metal content in soils surrounding a Power Plant. Pol. J. Environ. Stud. 19 (4), 849, 2010.

31. VOLUNGEVIČIUS J., SKORUPSKAS R. Classification of anthropogenic soil transformation. Geologija 53, 4 (76), 165, 2011.

32. HONG H., CHENG F., YIN K., CHURCHMAN G.J., WANG C. Three-component mixed-layer illite/smectite/kaolinite $(\mathrm{I} / \mathrm{S} / \mathrm{K})$ minerals in hydromorphic soils, south China. Am. Mineral., 100, 1883, 2015.

33. AKAY A., DOULATI B. The Effect of Soil Properties on Zn Adsorption. J. Int. Environ. Appl. Sci., 7 (1), 151, 2012.

34. DIATTA J.B., WITCZAK R., SKUBISZEWSKA A. Zinc dynamics in an arable soil as affected by plant residues incorporation: agroenvironmental concern. Fresen. Environ. Bull. 18 (10a), 1957, 2009.

35. DIATTA J., BIBER M., PRZYGOCKA-CYNA K., ŁUKOWIAK R. Application of soil-plant transfer coefficients and plant pollution indices for evaluating heavy metal contamination within the Marcinkowski's Recreational Park (Poznań). Nauka Przyr. Technol. 5, 5, \#79, ISSN 1897-7820 (http://www.npt.up-poznan.net), 2011.

36. LINDSAY W.L. Chemical equilibria in soils. New York, NY, USA, John, Wiley and Sons, Inc. 1979.

37. ALLOWAY B.J. Zinc in soils and crop nutrition. 2nd Ed. Int. published by IZA and IFA. Zinc Association, Brussels and Paris. ISBN 978-90-8133-310-8, 1-139, 2008.

38. RUTKOWSKA B., SZULC W., BOMZE K., GOZDOWSKI D., SPYCHAJ-FABISIAK E. Soil factors affecting solubility and mobility of zinc in contaminated soils. Int. J. Environ. Sci. Technol. 12, 1687, 2015.

39. STEPHAN C.H., COURCHESNE F., HENDERSHOT W.H., MCGRATH S.P., CHAUDRI A.M., SAPPIN-DIDIER V., SAUVE S. Speciation of zinc in contaminated soils. Environ. Pollut. 155 (2), 208, 2008.

40. STIETIYA M.H. Sorption mechanisms of zinc in different clay minerals and soil systems as influenced by various natural ligands. $\mathrm{PhD}$, Graduate Faculty of the Louisiana State University and Agricultural and Mechanical College, 214, 2010.

41. KIEPUL J., GEDIGA K. The effect of progressive acidification of lessive soil on zinc content and its translocation in soil profile. J. Elementol. 14 (2), 265, 2009.

42. LIN W., XIAO T., ZHOU W., NING Z. Pb, Zn, and Cd Distribution and Migration at a Historical Zinc Smelting Site. Pol. J. Environ. Stud. 24 (2), 575, 2015.

43. DIATTA J., CHUDZIŃSKA E. Chemical remediation of zinc contaminated soils by applying a cement-brown coal-based component (Cembro). Environ. Protect. Natur. Resour. 41, 89, 2009.

44. WUANA R.A., OKIEIMEN F.E. Heavy Metals in Contaminated Soils: A Review of Sources, Chemistry, Risks and Best Available Strategies for Remediation. International Scholarly Research Network (ISRN) Ecology 2011, Article ID 402647, 2011.

45. SCHULTEN H.R., LEINWEBER P. New insights into organic-mineral particles: composition, properties and models of molecular structure. Biol. Fertil. Soils, 30, 399, 2000.

46. UCHIMIYA M., LIMA I.M., KLASSON K.T., WARTELLE L.H. Contaminant immobilization and nutrient release by biochar soil amendment: roles of natural organic matter. Chemosphere 80 (8), 935, 2010.

47. SEQUI P., De NOBILI M. Carbonio organico. In: Metodi di analisi chimica del suolo (Coordinatore P. Violante). Collana di metodi analitici per l'agricoltura diretta da P. Sequi. Franco Angeli, Milano, Capitolo VII, 1-5, 2000.

48. DANDANMOZD F., HOSSEINPUR A.R. Thermodynamic parameters of zinc sorption in some calcareous soils. Journal of American Science 6 (7), 298, 2010.

49. DASKALOPOULOU K., CALABRESE S., MiLAZZO S., BRUSCA L., BELLOMO S., D'ALESSANDRO W., KYRIAKOPOULOS K., TASSI F., PARELLO F. Trace elements mobility in soils from the hydrothermal area of Nisyros (Greece). Annals of Geophysics, Fast Track 2, 1, 2014.

50. GUPTA S.K., VOLLMER M.K and KREBS R. The importance of mobile, mobilisable and pseudo total metal fractions in soil for three-level risk assessment and risk management. Sci. Total Environ. 178, 11, 1996.

51. GAŁUSZKA A. Different Approaches in Using and Understanding the Term "Geochemical Background" Practical Implications for Environmental Studies. Pol. J. Environ. Stud. 16, 3, 389, 2007.

52. KABATA-PENDIAS A., PENDIAS H. Trace elements in soils and plants. CRC Press, Boca Raton, 2001.

53. CZARNOWSKA K. Total heavy metals content in bedrocks as a soil geochemical background. Rocz. Gleboznaw. Tom XLVII Supplement. Warsaw, 43, 1996 [In Polish].

54. JEYAKUMAR P., LOGANATHAN P., ANDERSON C.W., SIVAKUMARAN S., McLAREN R.G. Comparative tolerance of Pinus radiata and microbial activity to copper and zinc in a soil treated with metal-amended biosolids. Environ Sci. Pollut. Res. Int. 21 (5), 3254, 2014.

55. PROUST D. An Integrated Geochemical and Mineralogical Approach for the Evaluation of $\mathrm{Zn}$ Distribution in LongTerm Sludge-Amended Soil. J. Soil Sci. 5, 251, 2015.

56. LIN W., XIAO T., ZHOU W., NING Z. Pb, Zn, and Cd Distribution and Migration at a Historical Zinc Smelting Site. Pol. J. Environ. Stud. 24 (2), 575, 2015.

57. GUPTA S.K., ATEN C. Comparison and evaluation of extraction media and their suitability in a simple model to predict the biological relevance of heavy metal concentrations in contaminated soils. Int. J. Environ. Anal. Chem. 51, 25, 1993.

58. BENJANIN M.M., LECKIE J.O. Multiple-site adsorption of $\mathrm{Cd}, \mathrm{Cu}, \mathrm{Zn}$ and $\mathrm{Pb}$ on amorphous iron oxy-hydroxide. J. Colloid Interface Sci. 79, 209, 1981.

59. CHRISTENSEN T.H., ASTRUP T., BODDUM J.K., HANSEN B.Ø., REDEMANN S. Copper and zinc distribution coefficients for sandy aquifer material. Water Res. 34 (3), 709, 2000.

60. WYSZKOWSKI M., MODRZEWSKA B. Acidity and sorption properties of zinc-contaminated soil following the application of neutralising substances. J. Environ. Eng. 17 (1), 63, 2016.

61. GONET B. Free radicals of the pine needles as an indicator of damage to forests caused by car exhaust gases. Curr. Top. Biophys. 33 (A), 73, 2010.

62. VILČINSKAS R., KUPČINSKIENĖ E. Seasonal dynamics of histological parameters of the needles of Scots pine (Pinus sylvestris L.) growing in conditions of excess ammonia. Biologija. 58 (1), 27, 2012.

63. BAŞLAR S., DOĞAN Y., BAĞ H., ELÇI A. Trace elements biomonitoring by needles of Pinus brutia TEN. From Western Anatolia, Turkey. Fresen. Environ. Bull. 12 (5), 450, 2003. 
64. BIAŁOBOK S., BORATYŃSKI A., BUGAŁA W. The biology of Scots pine, PAN Institute of Dendrology, Kórnik - Eds. Sorus, Poznan, 624, 1993 [In Polish].
65. JELONEK T., PAZDROWSKI W., WALKOWIAK R., ARASIMOWICZ-JELONEK M., TOMCZAKA. Allometric Models of Foliage Biomass in Scots Pine (Pinus sylvestris L.). Pol. J. Environ. Stud., 20 (2), 355, 2011. 